\section{The change of tissue of inhibitor metalloproteinase 1 (timp-1) after rosella (hibiscus sabdariffa) extract gel application on artificial crown patients with gingivitis}

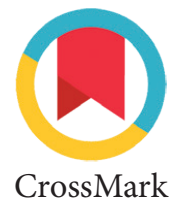

\author{
Lenni Indriyani, ${ }^{1 *}$ Mochammad Dharmautama, ${ }^{2}$ \\ Maqhfirah Amiruddin, ${ }^{2}$ Ike D. Habar ${ }^{2}$
}

containing rosella extract as therapy on standards gingivitis treatment in patients with artificial crown.

Results: Antimicrobial test of Rosella flower extract on P. gingivalis and $S$. Sanguis bacteria showed that antimicrobial effectiveness of Rosella flower extract was found at concentration of $10 \%$.

Conclusion: $10 \%$ rosella gel extracts can be used as an alternative ingredients in standard gingival inflammation treatment due to artificial acrylic crown using.

Keywords: Rosella gel extract, TIMP-1

Cite this Article: Indriyani L, Dharmautama M, Amiruddin M, Habar ID. 2019. The change of tissue of inhibitor metalloproteinase 1 (timp-1) after rosella (hibiscus sabdariffa) extract gel application on artificial crown patients with gingivitis. Journal of Dentomaxillofacial Science 4(1): 39-43. D01:10.15562/jdmfs.v4i1.692

${ }^{1}$ Department of Dental Material, Faculty of Dentistry, Hasanuddin University, Makassar, Indonesia ${ }^{2}$ Department of Prosthodontics, Faculty of Dentistry, Hasanuddin University, Makassar, Indonesia
*Correspondence to: Lenni Indriyani, Department of Dental Material, Faculty of Dentistry, Hasanuddin University, Makassar, Indonesia

lenni_601@yahoo.co.id

Received: 16 March 2016 Revised: 15 August 2016 Accepted: 17 August 2016 Available Online 1 April 2019

\section{Introduction}

Acrylic crown is commonly used as a restoration to covering tooth temporarily and after tooth preparation. ${ }^{1}$ Distribution and frequency care with artificial crown based on age range, the most frequent age is $20-29$, on vital teeth $(24.7 \%)$ and nonvital teeth (45.2\%). ${ }^{2}$ Restoration material character as surface roughness, can influence bacteria layer attachment that caused by availability surface for bacteria attachment and protect bacteria colonization. ${ }^{3}$ Even in some research currently focus on researching relationship between denture and periodontal tissues inflammation and not on periodontal damage.

Tissue inhibitor metalloproteinase-1 (TIMP-1) is inhibitors from matrix metalloproteinase-8 (MMP). TIMP-1 have various biological activity formed cell proliferation modulation, migration and invasion cell, anti-angiogenesis, anti and proaptosis. Most of the activity comes from the inhibition of MMP-8, as extracellular matrix catabolism regulation (ECM) which may affect the cells. ${ }^{4}$ Tissue inhibitor metalloproteinase-1 (TIMP-1) is to promote proliferation on all cell type and act as an anti-apoptotic. Paalike and aiba suggested that TIMP-1 is more effective on inhibiting the activity of collagenase interstitial or matrix metalloproteinase-8 (MMP-8). ${ }^{5}$

The use of natural ingredients in the world of health tends to increase from year to year, not least in the field of dentistry. Proper scientific evaluation of these herbal medicines is imperative in order to establish their efficacy and safety. Rosella (Hibiscus Sabdariffa) is an annual dicotyledonous shrub, grows to a height of about two meters with yellow or reddish flower and the leaves have three to five lobules. Many parts of the plant are of value with the leaves, seeds and calyces widely used as either food or drug. ${ }^{6}$ Rosella (Hibiscus sabdariffa) contains flavonoids with antioxidant activity. The dominant compounds in rosella flowers include quercetin, sianidin, $\beta$ carotene and vitamin C. ${ }^{7}$ The presence of certain bioactive agents, such as phenolics, ascorbic acid, certains sugars and trace metallic elements with proven intrinsic wound healing activities make rosella a agent potential for wound healing. ${ }^{6}$

From the previous study, fever entails enhanced formation of cytokines such as interleukins (IL), interferons and tumour necrosis factor-a (TNF-a). The Hibiscus Sabdariffa extract may be involved in the inhibition of some of these substances, resulting also in an anti-inflammatory effect. ${ }^{8}$ The flavonoids, polysaccharides and organic acids might be the compounds responsible for the pharmacological activity. In a more recent study the ethanolic extract from the calyces also showed antinociceptive effect in a rat model. ${ }^{9}$ Another in vivo study showed that the two fractions of the crude aqueous-ethanolic extract of the dried Hibiscus Sabdariffa exhibited impressive immunostimulatory activity by increasing the production of IL-10 and 


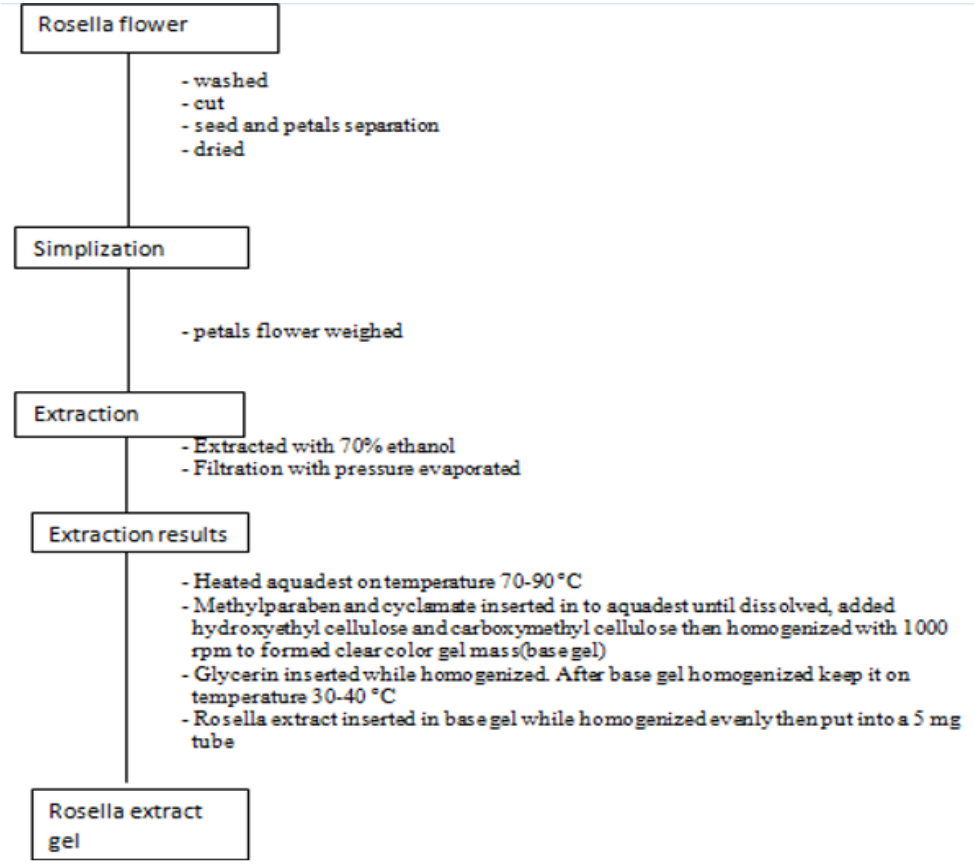

Figure 1 Extraction rosella extract and creating extract rosella gel

and decreasing the production of TNF-a. ${ }^{10}$ Other study suggests the combination of gentamicin cream with cream from rosella flower extract is able to give the effect of wound healing accelerate wound healing. ${ }^{6}$

From the data, gingivitis often occurs after the insertion of acrylic crowns and some studies on the effectiveness of rosella flower extract has been done and considered safe for the body and see many benefits of rosella flower extract and the need to develop products other than beverages and food. ${ }^{11}$ The purpose of this study was to investigate the increase of TIMP-1 gingival crevicular fluid after application of rosella flower extract gel on gingiva as the standard treatment of gingivitis after insertion of acrylic crown.

\section{Material and Methods}

This research Type was pure experimental research using randomized design on pre- and post-t-test with control group (the randomized pretest-posttest control group design). Clinical test (in vivo test) were done to determine the effect gel therapeutic containing Rosella extract as therapy on standards gingivitis treatment in patients with artificial crown. Study design in this study was pre-post test with control group experimental figure 1 .

Population for this study was all patients who attending to Department of Prosthodontic the Hospital of the Faculty Dentistry Hasanuddin University using acrylic crown. Sample for this research is all patients who meet criteria that used acrylic crown on maxillary anterior teeth with gingivitis. Control was maxillary anterior tooth using acrylic crown treated with non rosella gel and povidone iodine.

Figure 2 and figure 3 showed the study sample that consist of 9 people were divided into 3 groups. Group 1: therapy with rosella extract gel, group 2: treatment with a base gel (without rosella) as negative control as much as 3. Group 3: therapy with povidone-iodine as positive control as much as 3 people.

\section{Results}

Prior to clinical trials, an antimicrobial test was iniatially performed to determine the concentration of Rosella flower extract to be used in gel preparation. The result of antimicrobial test of rosella flower extract on P. gingivalis and S. Sanguis bacteria showed that antimicrobial effectiveness of rosella flower extract was found at concentration of $10 \%$.

Subject study as many as 9 people with gingivitis after artificial acrylic crown insertion, were divided into 3 groups assessment randomly; each 3 people to treatment group (given rosella extract gel), 3 to negative control group (given a base gel) and positive control group (given povidoneiodine). Clinical observation such as plaque index score and gingivitis index examination and GCF was done before and after gel application (pre and post test) to examine the expression changing of TIMP-1 mRNA gene. The result was displayed with systematic as following.

Results of demographics characteristics analysis showed that subject aged 20-25 years, with the most frequency was aged 21-year-old. Consists of 6 women and 3 men. Gender and age distributed equally on all groups table 1 .

Effect of rosella gel extract application on expression changing in TIMP-1 gene of GCF as standards gingivitis treatment after acrylic crown insertion. To value the effect of rosella gel extract application on expression changing in TIMP-1 mRNA of GCF as standard gingivitis treatment after artificial crown placement, analysis were made with paired $t$ test on each group, the results could seen on table 2 .

Table 2 showed that on negative control group (base gel) there was no significant change in TIMP-1 mRNA expression of GCF ( $p>0.05)$; but on treatment group (rosella extract), although there was no significant increase $(\mathrm{p}>0.05)$, but showed an increase of 4.132 (2.316) ie from pretest of 9.998 (1.684) to posttest at 14.130 (0.752) while on positive control group (povidone-iodine), although increased to 3.448 (1.149) from 12.003 (2.387) to - 
Table 1 Demographics characteristics of subject research

\begin{tabular}{llccc}
\hline Demographic Characteristics & $\begin{array}{c}\text { Treatment } \\
\text { (Rosella B gel extract) }\end{array}$ & $\begin{array}{c}\text { Group } \\
\text { Negative Control } \\
\text { (Base Gel) }\end{array}$ & $\begin{array}{c}\text { Positive control } \\
\text { (Povidon lodine) }\end{array}$ \\
\hline Age (years) & $20(\mathrm{n}=2)$ & 2 & 0 & 0 \\
& $21(\mathrm{n}=4)$ & 1 & 1 & 2 \\
Gender & $25(\mathrm{n}=3)$ & 0 & 2 & 1 \\
& male $(\mathrm{n}=3)$ & 1 & 1 & 1 \\
\hline
\end{tabular}

Table 2 Comparison of expression changing in TIMP-1 mRNA of GCF based on group

\begin{tabular}{lcccc}
\hline \multirow{2}{*}{ Group } & \multicolumn{2}{c}{ Expression changing in TIMP-1 mRNA of GCF } & \multirow{2}{*}{ Change } & P \\
\hline Rosella B gel extract & $9.998(1.684)$ & $14.130(0.752)$ & $-4.132(2.316)$ & 0.091 \\
Base gel & $13.222(0.201)$ & $13.352(0.335)$ & $-0.129(0.176)$ & 0.332 \\
Povidon iodine & $12.003(2.387)$ & $15.452(3.311)$ & $-3.448(1.149)$ & 0.035 \\
\hline
\end{tabular}

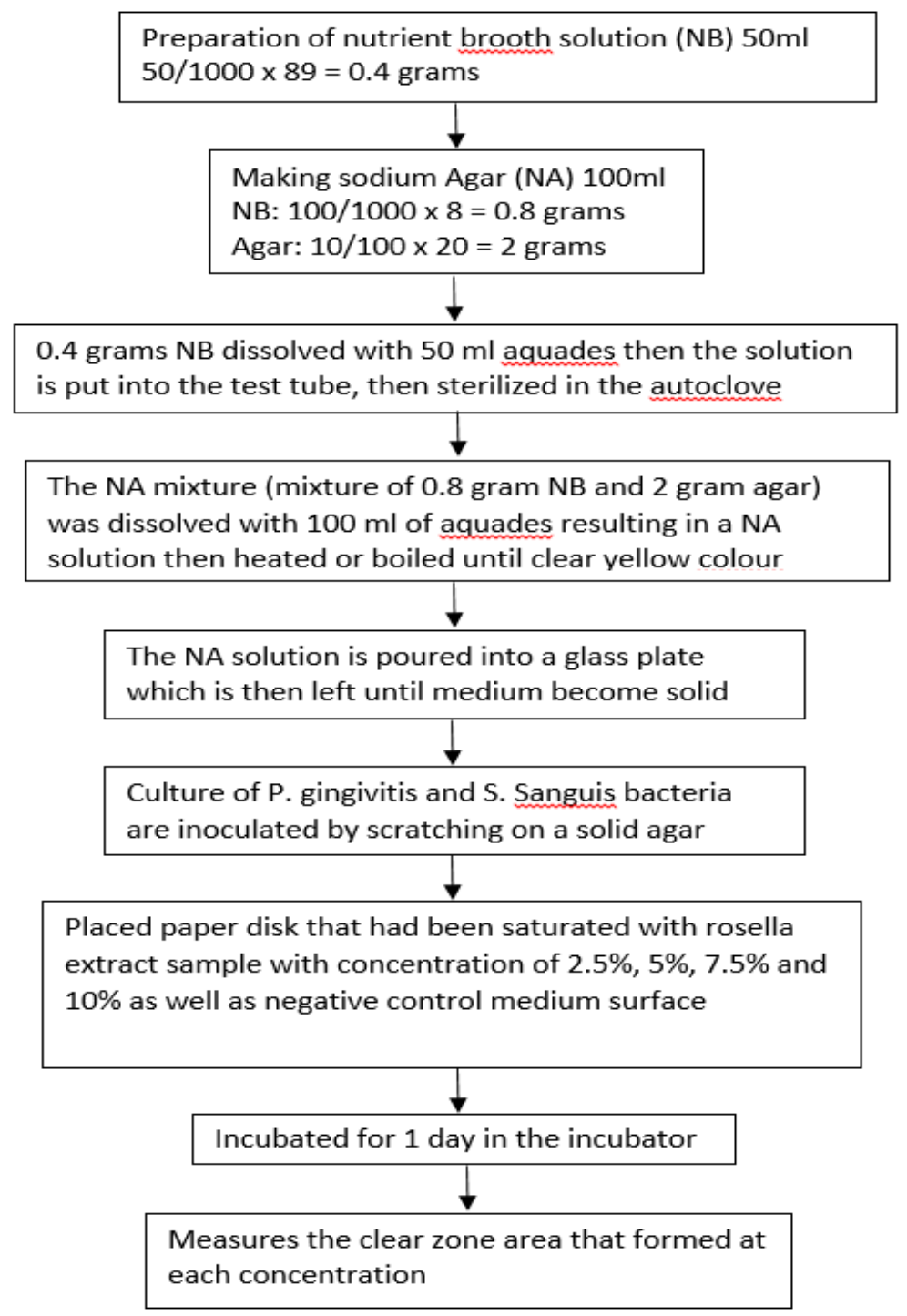

Figure 2 Antimicrobial test flowchart (preliminary test) 


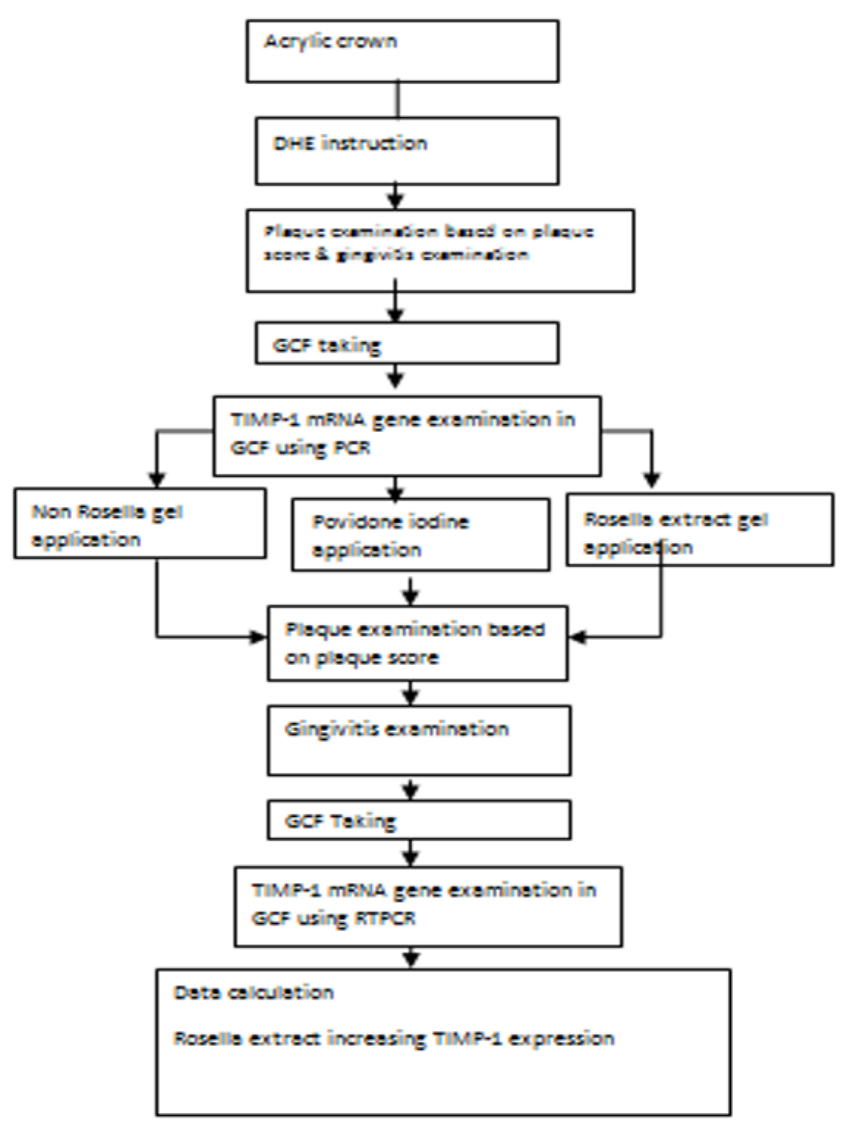

Figure 3 Rosella flower's effect flowchart

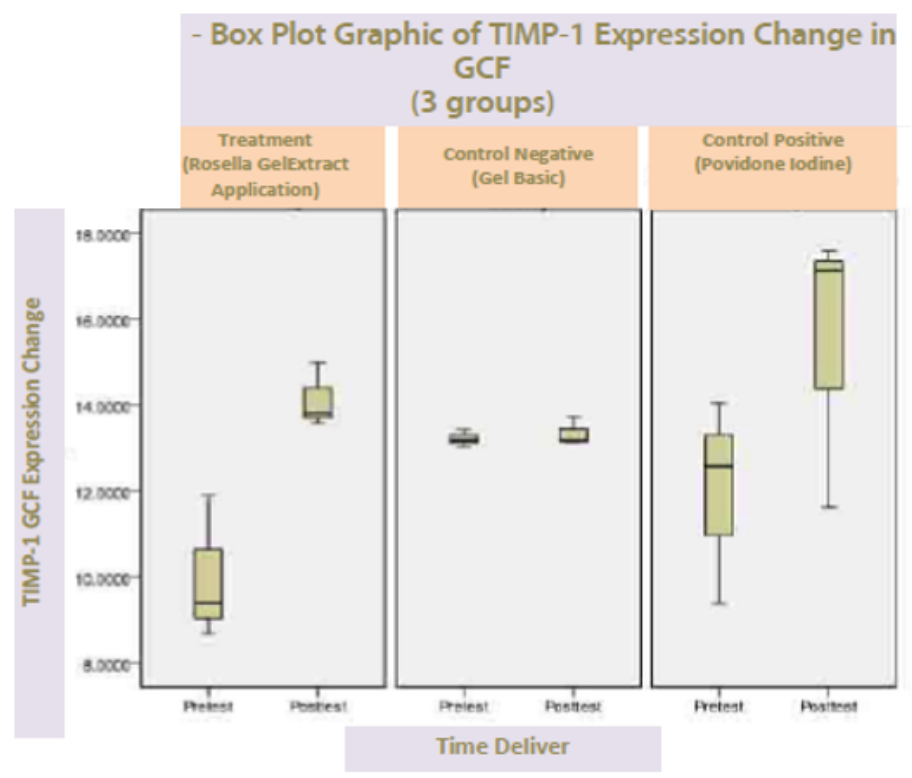

Figure 4 Box plot chart expression changing in pretest and posttest of TIMP-1 mRNA of GCF in all groups
15.452 (3.311) but statistically significant $(\mathrm{p}<0.05)$.

Figure 4 showed the improvement on treatment group and positive control regarding expression changing in pre text and post test of TIMP-1 mRNA of GCF while on negative control group did not show any change at all.

\section{Discussion}

Expression changing in TIMP-1 gene on this study were TIMP-1 improvement after $10 \%$ rosella extract gel application. This was supported by phytochemical that contained in Rosella like Anthocyanins and antosianitidin that have wound healing function. Previous study showed that there was difference in gingivitis healing rapidity postscaling between treatment group (rinsing with rosella flower tea) with controls group $(\mathrm{p}<0.05)$. So it concluded that rinsing with rosella tea is more effective to accelerate gingivitis healing postscaling. It could be seen that povidone iodine also able to increase TIMP-1, povidone iodine did not have healing wound effect.

Based on box plot chart, application of rosella extract gel on gingivitis area after artificial acrylic crown placement evidently could increase TIMP-1 level so that TIMP-1 activity could inhibit further damage caused by MMP-8.

\section{Conclusion}

The results showed in accordance with the study hypothesis so that it can be concluded: effect of $10 \%$ Rosella extract gel on gingivitis area after acrylic crown placement evidently could improve TIMP1 mRNA, 10\% Rosella gel extracts can be used asone alternative ingredients in standard gingival inflammation treatment due to artificial acrylic crown usage.

\section{Aknowledgment}

The authors would like to acknowledge all parties involved in this study.

\section{Conflict of Interest}

The authors report no conflict of interest.

\section{References}

1. McCabe JF, Walls AWG. Aplied dental Material, 9th ed. Blackwell Publishing; 2008. p. 30.

2. Oginni AO, Olusile AO, Udoye CI. Distribution and types of artificial crowns and bridges prescribes at a nigeriam teaching hospital. Nigerian J Clin Prac 2004;7: 24-27. 
3. Auschill TM, Arweilier NB, Breex M, et al. The effect of dental restorative materials on dental biofilm. Eur J Oral Sci 2002;110: 48-53.

4. Brew K, Nagase H. The tissue inhibitors of metalloproteinases (TIMPs): An ancient family with structural and functional diversity. Biochim Biophys Acta 2010;1803: 55-71.

5. Aiba T, Akeno N, Kawane $\mathrm{T}$, et al. Matrix metalloproteinases- 1 and -8 and TIMP-1 mRNA levels in normal and diseased human gingivae. Eur J Oral Sci 1996;104: 562-569.

6. Builders PF, Kabele-Toge B, Isimi YC. Wound healing potential of formulated extract from hibiscus sabdariffa calyx. Indiab J Pharma Sci 1996;104: 562-569.

7. Nurkhasanah, Yuwono T. The development of chitosan nanoparticles from hibiscus sabdariffa 1 calyx extract from Indonesia and Thailand. Int J of Pharmaceutic Sci \& Res 2015;6: 1855-1860.
8. Reanmongkol W, Itharat A. Antipyretic activity of the extracts of hibiscus sabdarixffa calyces L. in experimental animals. The songklanakarin. J Sci \& Technol 2007;29.

9. Dafallah AA, al-Mustafa Z. Investigation of the antiinflammatory activity of acacia nilotica and Hibiscus sabdariffa. The Am J Chinese Med 1996;24: 263-269.

10. Fakeye T. Toxicity and immunomodulatory activity of hibiscus sabdariffa Linn (family malvaceae) in animal models. African J Trad Complement \& Alt Med 2008;5: 394-398.

11. I Da-Costa-Rocha. Hibiscus sabdariffa L, a phytochemical and pharmacological review. Food Chemist J 2014;165: 424-444.

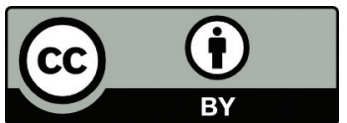

This work is licensed under a Creative Commons Attribution 